\title{
Methanogenic activity and biomass in Holocene permafrost deposits of the Lena Delta, Siberian Arctic and its implication for the global methane budget
}

\author{
DIRK WAGNER*, ANDREAS GATTINGER†, ARNDT EMBACHER , \\ EVA-MARIA PFEIFFER*1, MICHAEL SCHLOTER $\ddagger$ and ANDRÉ LIPSKI§ \\ *Research Department Potsdam, Alfred Wegener Institute for Polar and Marine Research, Telegrafenberg A45, 14473 Potsdam,

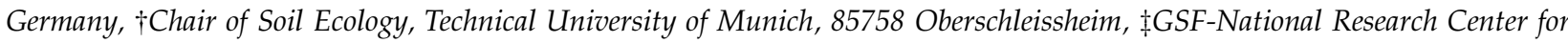 \\ Environment and Health, Institute of Soil Ecology, Ingolstädter Landstraße 1, 85764 Neuherberg, Germany, §Department of \\ Microbiology, University Osnabrück, 49069 Osnabrück, Germany
}

\begin{abstract}
Permafrost environments within the Siberian Arctic are natural sources of the climate relevant trace gas methane. In order to improve our understanding of the present and future carbon dynamics in high latitudes, we studied the methane concentration, the quantity and quality of organic matter, and the activity and biomass of the methanogenic community in permafrost deposits. For these investigations a permafrost core of Holocene age was drilled in the Lena Delta $\left(72^{\circ} 22^{\prime} \mathrm{N}, 126^{\circ} 28^{\prime} \mathrm{E}\right)$. The organic carbon of the permafrost sediments varied between $0.6 \%$ and $4.9 \%$ and was characterized by an increasing humification index with permafrost depth. A high $\mathrm{CH}_{4}$ concentration was found in the upper $4 \mathrm{~m}$ of the deposits, which correlates well with the methanogenic activity and archaeal biomass (expressed as PLEL concentration). Even the incubation of core material at -3 and $-6{ }^{\circ} \mathrm{C}$ with and without substrates showed a significant $\mathrm{CH}_{4}$ production (range: $0.04-0.78 \mathrm{nmol} \mathrm{CH}_{4} \mathrm{~h}^{-1} \mathrm{~g}^{-1}$ ). The results indicated that the methane in Holocene permafrost deposits of the Lena Delta originated from modern methanogenesis by cold-adapted methanogenic archaea. Microbial generated methane in permafrost sediments is so far an underestimated factor for the future climate development.
\end{abstract}

Keywords: methane, methane release, methanogenesis, permafrost deposits, phospholipid biomarker, psychrophiles

Received 13 July 2006; revised version received 14 December 2006 and accepted 16 December 2006

\section{Introduction}

Northern wetlands play an important role within the global methane cycle. Methane is chemically very reactive and more efficient in absorbing infrared radiation than carbon dioxide. Estimates of the methane emissions of arctic and subarctic wetlands range between 10 and $39 \mathrm{Tg} \mathrm{a}^{-1}$, or between $2.2 \%$ and $8.6 \%$ of the global methane emission (Bartlett \& Harriss, 1993; Cao et al., 1998). Methane as a powerful greenhouse gas contributes to about $20 \%$ of the global warming (IPCC, 2001).

Correspondence: D. Wagner, tel. +49 331288 2159, fax +49 331 288 2137, e-mail: Dirk.Wagner@awi.de

${ }^{1}$ Present address: Institute of Soil Science, University Hamburg, Allende-Platz 2, 20146 Hamburg.

(C) 2007 The Authors

Journal compilation (C) 2007 Blackwell Publishing Ltd
Permafrost, which appears mainly in polar and subpolar regions, occurs within about $25 \%$ of the land surface (Zhang et al., 1999). It can be divided into three temperature depth zones which characterize typical living conditions: (i) the active layer with an extreme temperature regime from about +15 to $-35^{\circ} \mathrm{C}$, (ii) the correlated upper permafrost sediments $(0.5-20 \mathrm{~m}$ thickness) with smaller seasonal temperature variation of about 0 to $-15^{\circ} \mathrm{C}$ above the zero annual amplitude and (iii) the deeper permafrost sediments which are characterized by a stable temperature regime of about -5 to $-10{ }^{\circ} \mathrm{C}$ (French, 1996).

A considerable amount of organic carbon is stored in the upper permafrost layers, indicating that the extreme Arctic climate condition reduces the organic carbon decomposition rate more than the net primary production rate (Oechel et al., 1997). The positive temperature 
trend in the Russian Arctic favours warming and thawing of terrestrial permafrost (Richter-Menge et al., 2006). The degradation of permafrost and the associated release of climate relevant trace gases, as a consequence of an intensified turnover of organic carbon and from ancient methane reservoirs, represent a potential risk with respect to future global warming. At this point, the functioning of microbial communities and their reaction on changing environmental conditions are not adequately understood, neither the potential methane releases from frozen sediments are adequately quantified.

In general, temperature is one of the most important variables regulating the activity of microorganisms. The potential of growth, as well as the molecular, physiological and ecological aspects of microbial life at low temperatures have been investigated in many studies (e.g. Russel \& Hamamoto, 1998; Gounot, 1999; Cavicchioli, 2006). Certain key processes of the methane cycles are carried out exclusively by highly specialized microorganisms such as methanogenic archaea and methane oxidizing bacteria. The microbial methane production (methanogenesis) in the active layer of permafrost is the terminal step during the anaerobic decomposition of organic matter, while the methane oxidation is the primary sink for methane in Arctic wetlands (Wagner et al., 2005). With recent findings it becomes evident that methanogenic archaea and methane oxidizing bacteria also exist in permafrost soils, with numbers comparable to those in moderate soil environments (Kobabe et al., 2004; Liebner \& Wagner, 2007).

However, there are only few studies investigating the geochemistry and microbiology of permafrost deposits, mainly in Siberia and Canada. Direct bacterial counts in the order of $10^{7}-10^{8}$ were reported for permafrost deposits from Northeast Siberia (Rivkina et al., 1998). Furthermore, Shi et al. (1997) found viable bacteria in permafrost sediments up to 3 million years in age in the Kolyma-Indigirka lowlands. Most of the isolated bacteria showed mesophilic growth characteristics. In contrast, the minimum temperature for growth of permafrost bacteria was recently calculated with $-20^{\circ} \mathrm{C}$ (Rivkina et al., 2000). Furthermore, molecular life markers and low numbers of methanogens were found in the Mallik gas hydrate production research well (Colwell et al., 2005; Mangelsdorf et al., 2005). However, methanogenic activity could not be detected in the permafrost sediments by using radiolabelled ${ }^{14} \mathrm{C}$-substrates.

So far, there is no proof for recent methanogenic activities in permafrost deposits. The main objective of this study was to identify the vertical position and quantify the methanogenic activity along a Holocene permafrost core from the Siberian Lena Delta, and correlate this activity with biotic and abiotic factors. A polyphasic cultivation-independent approach was used based on geochemical and microbiological methods to identify the origin of permafrost borne methane. As direct cultivation of methanogenic archaea from cold environments is limited to only very few species, we used etherlipids, which are a unique component of the archaeal cell membrane, as biomarkers to quantify methanogens along the permafrost core.

\section{Material and methods}

\section{Investigation area}

Within the scope of long-term studies on carbon dynamics in the Siberian Arctic, the LENA 2001 expedition was carried out by the Alfred Wegener Institute for Polar and Marine Research. The Lena Delta lies at the Laptev Sea coast between the Taimyr Peninsula and the New Siberian Islands. Continuous permafrost, which occurs throughout the investigation area extends to depths of about $100-300 \mathrm{~m}$ (Yershov, 1998). It is characterized by an arctic continental climate with low mean annual air temperature of $-14.7^{\circ} \mathrm{C}\left(T_{\min }=-48^{\circ} \mathrm{C}\right.$, $T_{\max }=18^{\circ} \mathrm{C}$ ) and low summer precipitation of $<198 \mathrm{~mm}$. The study site, Samoylov Island $\left(72^{\circ} 22^{\prime} \mathrm{N}\right.$, $126^{\circ} 28^{\prime}$ E) with the Russian-German Research Station Samoylov, is located in the active part of the Lena Delta (Hubberten et al., 2006). This part of the delta was formed during the Holocene with an age of about 9300 Bг. Further details of the study site were described previously by Wagner et al. (2003a).

\section{Permafrost drilling and preparation}

During summer 2001 a permafrost core of $850 \mathrm{~cm}$ length was drilled in the depression of a low-centred icewedge polygon on Samoylov Island. The drilling was carried out with a portable gasoline powered permafrost corer without using any drilling fluid to avoid microbiological contamination of the permafrost samples. A mixing of the permafrost sediments was not be observed due to the frozen state of the core material. The individual core segments, which were up to $50 \mathrm{~cm}$ in length, were placed immediately after removal from the corer into plastic bags and stored at about $-8^{\circ} \mathrm{C}$ in the permafrost cellar of the Research Station Samoylov. After drilling of the core the borehole temperature was monitored with a string of nine thermistors. The cores were transported in frozen conditions in insulated containers with cool packs to Potsdam, Germany. During the transport the temperatures in the containers were monitored by micro data loggers. The storage temperature in the Potsdam laboratory was $-22^{\circ} \mathrm{C}$. 
Core segments were split along their axis into two halves under aseptic conditions with a diamond saw in an ice laboratory at $-22^{\circ} \mathrm{C}$. Afterwards, one-half of the core was cleaned with a sterile knife for lithological and geocryologically descriptions. Subsequently, one-half was cut into segments of about $10-30 \mathrm{~cm}$ length according the lithology and the geocryology. Small pieces (approximately $10 \mathrm{~g}$ ) of each subsample were taken for analysing the methane concentration in the frozen sediments. The remaining material of each subsample was thawed at $4{ }^{\circ} \mathrm{C}$ and homogenized under anoxic and sterile conditions for analysis of the sediment properties and the microbial activities and biomarkers. Subsamples for the different analyses were filled into sterile plastic Nalgene boxes. Separated samples were used directly for the experiments (e.g. methane production, biomarker analysis) or were refrozen for later analyses at $-22{ }^{\circ} \mathrm{C}$. The second half of the core is kept as an archive in the ice core storage at the Alfred Wegener Institute.

\section{Sediment properties}

Grain-size distribution was analysed on bulk sediment samples for each segment, on average every $20 \mathrm{~cm}$. The sediments were oxidized using a $5 \% \mathrm{H}_{2} \mathrm{O}_{2}$ solution to remove organic matter from each sample. The gravel $(>2 \mathrm{~mm})$ and sand $(0.063-2.0 \mathrm{~mm})$ fractions were determined by wet sieving. The remaining silt $(0.002-0.063)$ and clay $(<0.002 \mathrm{~mm})$ material were separated by sedimentation in ammoniac water $\left(10 \mathrm{~mL} \mathrm{NH} \mathrm{NH}_{3}\right.$ in $100 \mathrm{~L}$ deionized water). From the dry weight (dw) of gravel, sand, silt and clay, the weight percentages of the bulk dry sediment were calculated for each fraction.

Radiocarbon dating was carried out for three selected samples $(289,557$ and $843 \mathrm{~cm}$ depth) with the Accelerator Mass Spectrometer (AMS) facility at the Leibniz Laboratory for Radiometric Dating and Stable Isotope Research, University of Kiel, Germany (Table 1). Standard calibration techniques (Stuiver et al., 1998) were used to express the sediment ages in calendar years before the present. A more detailed description of the equipment and method was given by Nadeau et al. $(1997,1998)$.

The total carbon (TC) and total nitrogen (TN) contents were determined with an automatic element analyser (Elementar VARIO EL III). The total organic carbon (TOC) content was measured on corresponding samples after $\mathrm{HCl}(10 \%)$ acid digestion to remove the carbonate on the same analyser (Elementar VARIO EL III). Based on TOC and TN values, the $\mathrm{C} / \mathrm{N}$ ratio was calculated. Analytical precision is $\pm 5 \%$ for element analyses.
Table 1 AMS radiocarbon dating, calendar years and $\delta^{13} \mathrm{C}$ values of the organic carbon fraction from selected permafrost sediments of Samoylov Island

\begin{tabular}{|c|c|c|c|c|c|}
\hline $\begin{array}{l}\text { Reference } \\
\text { number }\end{array}$ & $\begin{array}{l}\text { Depth } \\
(\mathrm{cm})\end{array}$ & Unit & $\begin{array}{l}{ }^{14} \mathrm{C} \text { age } \\
\text { (years BP) }\end{array}$ & $\begin{array}{l}\text { Calendar } \\
\text { age } \\
\text { (years BP) }\end{array}$ & $\delta^{13} \mathrm{C}(\%)$ \\
\hline KIA20719 & 289 & II & $2306 \pm 30$ & $2330 \pm 25$ & $-24.39 \pm 0.06$ \\
\hline KIA20720 & 557 & III & $7970 \pm 56$ & $8824 \pm 179$ & $-24.63 \pm 0.04$ \\
\hline KIA20721 & 843 & IV & $8295 \pm 50$ & $9334 \pm 101$ & $-23.06 \pm 0.03$ \\
\hline
\end{tabular}

$\mathrm{BP}=$ years before the present.

The humification index, a criterion for organic matter quality, was determined in the water extractable fraction of organic carbon as described in Wagner et al. (2005). In brief, the obtained aqueous extracts from frozen soil samples were subjected to optical measurements (UV absorption and fluorescence emission intensity). Dissolved organic matter differs in fluorescence behaviour in accordance to its molecular complexity. Humified carbon is characterized by highly substituted aromatic structures and condensed unsaturated systems. While their fluorescence emission lie in longer wavelengths, fresh and low humified organic matter fluoresce in the shorter wavelengths (Senesi et al., 1989). To quantify the humification of dissolved carbon we measured the fluorescence emission intensity in $1 \mathrm{~nm}$ steps between 300 and $480 \mathrm{~nm}$ with an excitation wavelength of $254 \mathrm{~nm}$ (Cary Eclipse F-4500, Varian ${ }^{\mathbb{R}}$, Varian, Palo Alto, CA, USA). Summarized intensities between 435 and $480 \mathrm{~nm}$ (upper quartile of the whole spectrum recording emission of more humified carbon) were divided by summarized intensities between 300 and $345 \mathrm{~nm}$ (lower quartile of the whole spectrum recording emission of less humified carbon), resulting in an dimensionless humification index (Zsolnay, 2003). The higher the humification index, the more the organic carbon in the samples is humified. All extracts were adjusted to $\mathrm{pH} 2$ as $\mathrm{pH}$ influences the fluorescence of organic molecules in solution (Zsolnay et al., 1999).

Vertical profiles of sediment $\mathrm{CH}_{4}$ concentrations were obtained from each segment by extracting $\mathrm{CH}_{4}$ from sediment pore water by thaw small frozen core material (approximately $10 \mathrm{~g}$ ) in saturated $\mathrm{NaCl}$ solution. The samples were then placed in glass jars and sealed gas tight with black rubber stoppers. The thawed samples were shaken and the $\mathrm{CH}_{4}$ headspace concentration was analysed with gas chromatography.

\section{$\mathrm{CH}_{4}$ production}

The $\mathrm{CH}_{4}$ production of permafrost sediments were analysed for each segment without any additional methanogenic substrate, or with acetate, and hydrogen 
as an energy source. Fresh sediments $(20 \mathrm{~g})$ were weighed in $100 \mathrm{~mL}$ glass jars and closed with a screw cap containing a septum. The samples were evacuated and flushed with ultra pure $\mathrm{N}_{2}$. Afterwards, the samples were supplemented with $6 \mathrm{~mL}$ sterile and anoxic tap water for analysing methane production without substrate addition. In the case of potential $\mathrm{CH}_{4}$ production $6 \mathrm{~mL}$ of acetate solution $(10 \mathrm{mM})$ or sterile and anoxic tap water in combination with $\mathrm{H}_{2} / \mathrm{CO}_{2}(80: 20$ $\mathrm{v} / \mathrm{v}$, pressurized $150 \mathrm{kPA}$ ) were added as substrates. Three replicates were used for each segment. The incubation temperature was $5^{\circ} \mathrm{C} . \mathrm{CH}_{4}$ production was measured daily over a period of 1 week by sampling the headspace using a Hamilton gastight syringe. $\mathrm{CH}_{4}$ production rates were calculated from the linear increase in $\mathrm{CH}_{4}$ concentration.

\section{Methane production at subzero temperature}

The $\mathrm{CH}_{4}$ production at subzero temperatures was analysed in samples from the upper part of the permafrost core (45-63 cm depth). The homogenized material $(10 \mathrm{~g})$ was directly weighed in $25 \mathrm{~mL}$ glass jars and closed with a screw cap containing a septum. The further preparation of the samples followed the description to the potential methane production activity. The prepared soil samples were incubated at -3 and $-6{ }^{\circ} \mathrm{C}$ for 14 and 21 days, respectively.

\section{Methane analysis}

Gas analysis were performed with an Agilent 6890 gas chromatograph equipped with a Carbonplot capillary column $(\varnothing 0.52 \mathrm{~mm}, 30 \mathrm{~m})$ and a flame ionization detector (FID). Helium was used as the carrier gas. The injector, oven and detector temperatures were set at 45 , 45 and $250{ }^{\circ} \mathrm{C}$, respectively. All gas sample analyses in the various experiments were done after calibration of the gas chromatograph with standard gases. After calibration the analytical reproducibility is $>98.5 \%$. Details of $\mathrm{CH}_{4}$ analysis were described previously in Wagner et al. (2003b).

\section{Determination of phospholipid fatty acids (PLFA) and phospholipid etherlipids (PLEL)}

Lipids were extracted from the freshly homogenized material from selected segments using an equivalent of about $30 \mathrm{~g}$ of $\mathrm{dw}$, according to the Bligh-Dyer method (Zelles \& Bai, 1993). The resulting lipid material was fractionated into neutral lipids, glycolipids and phospholipids on a silica-bonded phase column (SPE-SI; Bond Elute, Analytichem International, Harbor City, CA, USA) by elution with chloroform, acetone and methanol, respectively. An aliquot of the phospholipid fraction equivalent to $10 \mathrm{~g}$ soil $\mathrm{dw}$ was taken for PLFA analysis. After mild alkaline hydrolysis, the lipid extract was separated into OH-substituted ester-linked PLFA, non-OH substituted ester-linked PLFA and nonsaponifiable lipids following procedures described in Zelles \& Bai (1993). The fraction of unsubstituted ester-linked PLFA was reduced to dryness under nitrogen and dissolved in $100 \mu \mathrm{L}$ hexane supplemented with nonadecanoic methyl ester as internal standard. The analyses of the fatty acid methyl ester (FAME) extracts were performed by GC-MS as described in Lipski \& Altendorf (1997). The position of double bonds of monounsaturated fatty acids was determined by analysing the dimethyl disulphide (DMDS) adducts (Nichols et al., 1986). The fraction of nonsaponifiable lipids was cleaved during acidic hydrolysis and the resulting nonester-linked PLFA were separated into $\mathrm{OH}$-substituted nonester-linked PLFA (UNOH) and non-OH substituted nonester-linked PLFA (UNSFA). Separation of the nonester-linked PLFA, derivatization and measurement were performed according to Gattinger et al. (2002). Another aliquot of the phospholipid fraction equivalent to $20.0 \mathrm{~g}$ soil $\mathrm{dw}$ was used for PLEL analysis according to the method described by Gattinger et al. (2003). After the formation of ether core lipids, etherlinked isoprenoids were released following cleavage of ether bonds with $\mathrm{HI}$ and reductive dehalogenation with $\mathrm{Zn}$ in glacial acetic acid. The resulting isoprenoid hydrocarbons were dissolved in $100 \mu \mathrm{L}$ internal standard solution (nonadecanoic methyl ester) and subjected to GC/MS analysis at operating conditions described elsewhere (Gattinger et al., 2003). PLFA/PLEL concentrations are expressed in $\mathrm{nmolg}^{-1} \mathrm{dw}$.

\section{Statistical analysis}

Statistical analyses such as descriptive statistics and analysis of variance (ANOVA) were performed with SPSS software package release 12.0 (SPSS Inc., Chicago, IL, USA). The Kolmogorov-Smirnow test was used to assess distribution fitting. The definition of the four core units was based on the results of a constrained incremental sum of squares (CONISS) cluster analysis of the grain size data (using ZONE software version 1.2).

\section{Results}

\section{Abiotic characteristics of the permafrost sediments}

On basis of the grain size distribution and the subsequent CONISS analyses the permafrost core was separated into four units (I-IV). The further description of the results and the later discussion followed this classification. 
(a)

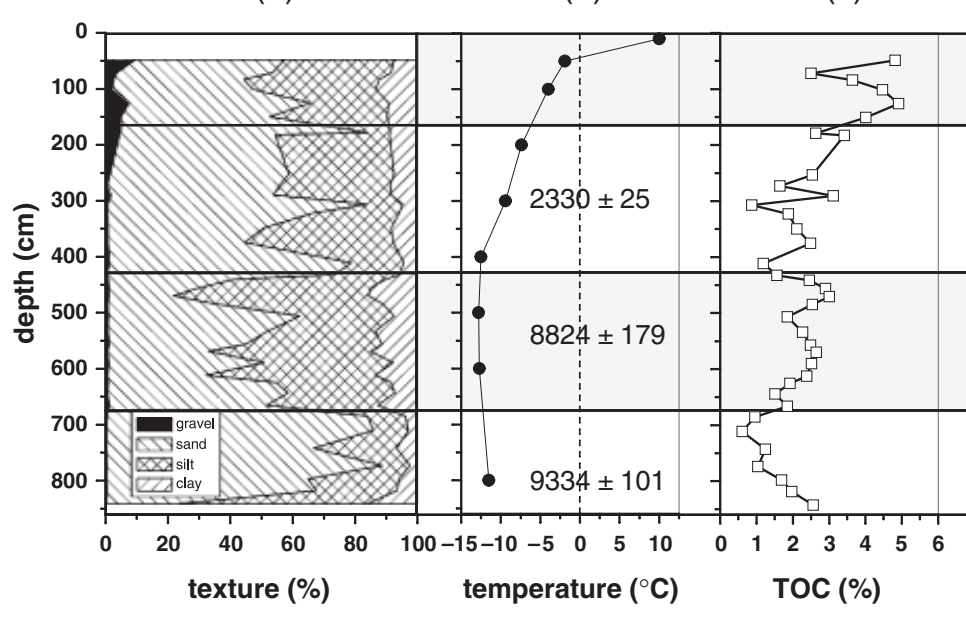

(d)

(e)

Fig. 1 Abiotic parameters of the Holocene permafrost deposits from Samoylov Island, Lena Delta (Siberian Arctic). (a) Sediment texture, (b) bore hole temperature and calendar years of selected sediment layers, (c) total organic carbon content (TOC), (d) humification index (HIX, dimensionless) and (e) C/N ratio. Calendar years (ВР) of selected sediment layers are denoted in graph (b). Units I-IV based on constrained incremental sum of squares (CONISS) analysis of the different grain size fractions.

The grain size analyses showed that gravel continuously decreased from the top to the bottom of the core $(4.9-0.2 \%)$. For the three other fractions (sand, silt and clay) a clear change between the different units was recognized. The average value of the sand fraction is highest in the Units II and IV (U-I $=48.2 \%$, $\mathrm{U}-\mathrm{II}=62.3 \%$, U-III $=42.6 \%$, U-IV $=68.2 \%$ ), while the highest values for silt (U-I $=36.4 \%$, U-II $=28.7 \%$, $\mathrm{U}-\mathrm{III}=44.7 \%$, U-IV $=24.9 \%)$ and clay $(\mathrm{U}-\mathrm{I}=10.5 \%$, $\mathrm{U}-\mathrm{II}=7.6 \%$ ，U-III $=11.8 \%$ ，U-IV $=6.7 \%$ ） were determined in the Units I and III (Fig. 1a). A steep temperature gradient was observed in the permafrost core, which ranged between $+10^{\circ} \mathrm{C}$ (near surface) and $-11.5^{\circ} \mathrm{C}$ at $800 \mathrm{~cm}$ depth. The median values were $-1.9,-9.4,-12.8$ and $-11.5^{\circ} \mathrm{C}$, for Units I-IV, respectively (Fig. 1b). The TOC content followed a depth gradient with median values between $4.2 \%$ and $1.3 \%$ for Units I-IV, respectively, but with significant variations within the vertical profile (Fig. 1c). A depth-dependent relationship can also be seen from the humification index (HIX) and the $\mathrm{C} / \mathrm{N}$ ratio. The HIX and $\mathrm{C} / \mathrm{N}$ ratio are both descriptors for organic matter quality. The lowest HIX values were found in Unit I (on average 5.1) which corresponded with the highest $\mathrm{C} / \mathrm{N}$ ratios (23.0). HIX was highest in Unit IV (on average 9.4) in accordance to a relatively low $\mathrm{C} / \mathrm{N}$ ratio of 15.7 (Fig. $1 \mathrm{~d}$ and e).

\section{Methane concentrations and potential methanogenic activities}

Methane was detected in all samples of the permafrost core. Highest concentrations were observed in Units I $\left(281.5 \mathrm{nmol} \mathrm{g}^{-1}\right)$ and II $\left(236.1 \mathrm{nmol} \mathrm{g}^{-1}\right)$. In Unit III, low values, ranging between 3.5 and $19.1 \mathrm{nmolg}^{-1}$ were detected, while only traces in the bottom zone of the core were found (0.4-1.9 $\mathrm{nmol} \mathrm{g}^{-1}$; Fig. 2a).

Methanogenic activity was determined at $5{ }^{\circ} \mathrm{C}$ with and without methanogenic substrates in selected sediment samples representative for the different core units. Methane production could be determined only in the two upper units (I, II), while in the lower two units (III, IV) no methane formation was detected before and after addition of methanogenic substrates (Fig. $2 b-d$ ). The methane production rates analysed in Unit I, were generally higher than in Unit II. In any case, the highest activity was observed in about $125 \mathrm{~cm}$ sediment depth, which corresponded on the highest concentration of methane (Fig. 2a-d).

The incubation of permafrost samples from 45 to $63 \mathrm{~cm}$ depth at subzero temperatures with acetate and hydrogen as methanogenic substrates indicated a relatively high methane production rate under permafrost temperature conditions (Figs $1 \mathrm{~b}$ and 3 ). At a temperature of $-3^{\circ} \mathrm{C}$ a significant increase in methane production was found, which rose linearly to headspace concentrations of about $1000 \mathrm{ppm}$ (with acetate) and $2500 \mathrm{ppm}$ (with hydrogen) during $300 \mathrm{~h}$ after the initiation of the experiment. At a temperature of $-6{ }^{\circ} \mathrm{C}$ methanogenesis was lower. However, after a lag phase of about $300 \mathrm{~h}$ a significant increase to $200 \mathrm{ppm}$ (with acetate) and $500 \mathrm{ppm}$ (with hydrogen) within $200 \mathrm{~h}$ was observed. The calculated activity of methanogenic archaea with hydrogen reached values of $0.78 \pm 0.31$ and $0.14 \mathrm{nmol} \mathrm{CH}_{4} \mathrm{~h}^{-1} \mathrm{~g}^{-1}$ at an incubation temperatures of -3 and $-6^{\circ} \mathrm{C}$, respectively. This was 2.5 and 3.5 times higher compared with the activity with acetate 
(a)

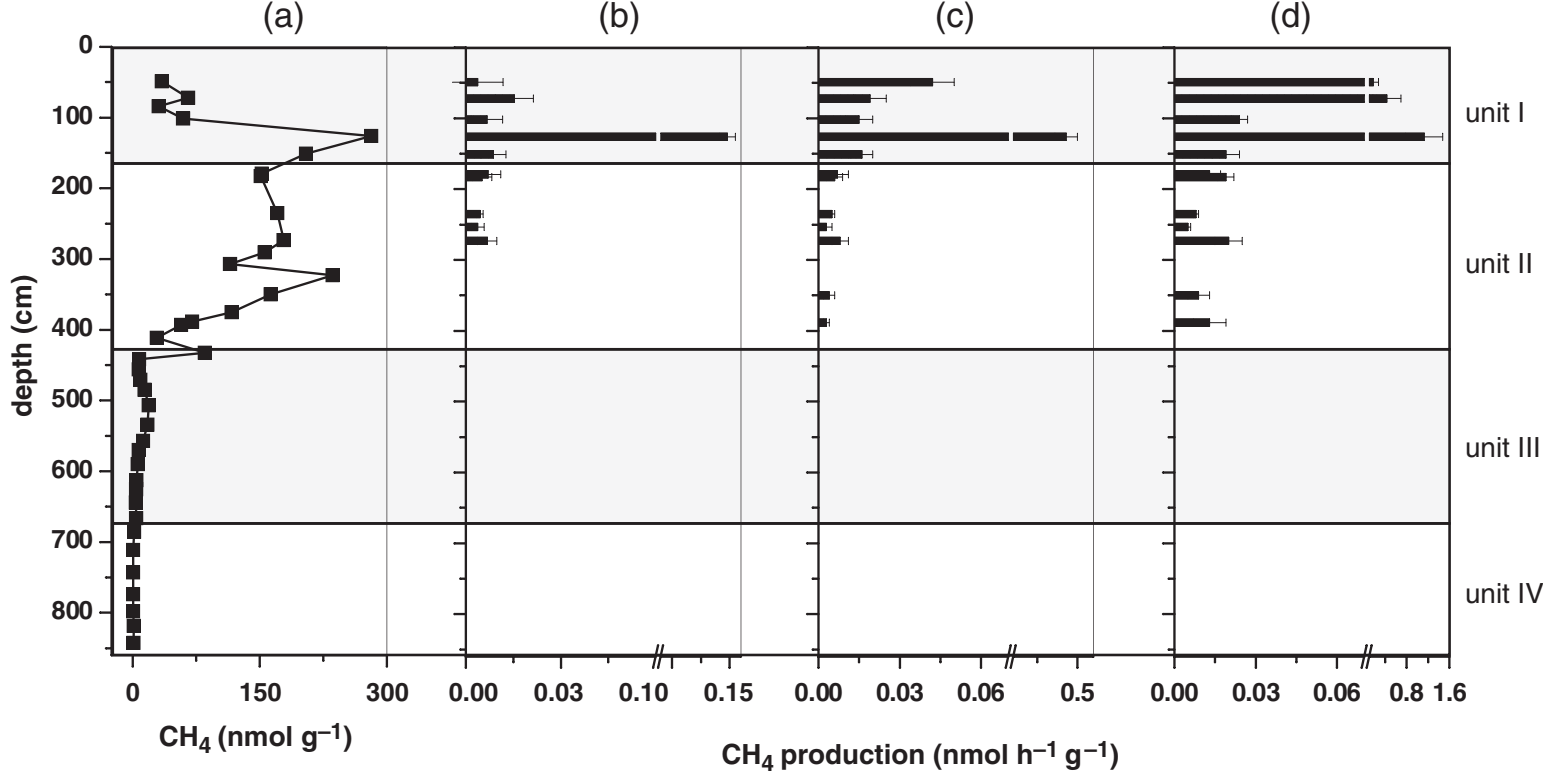

Fig. 2 Vertical profiles of methane concentration (a) and methane production rates determined at $5{ }^{\circ} \mathrm{C}$ without any additional substrate (b) as well as with acetate (c) or hydrogen (d) as methanogenic substrates. Units I-IV based on constrained incremental sum of squares (CONISS) analysis of the different grain size fractions.

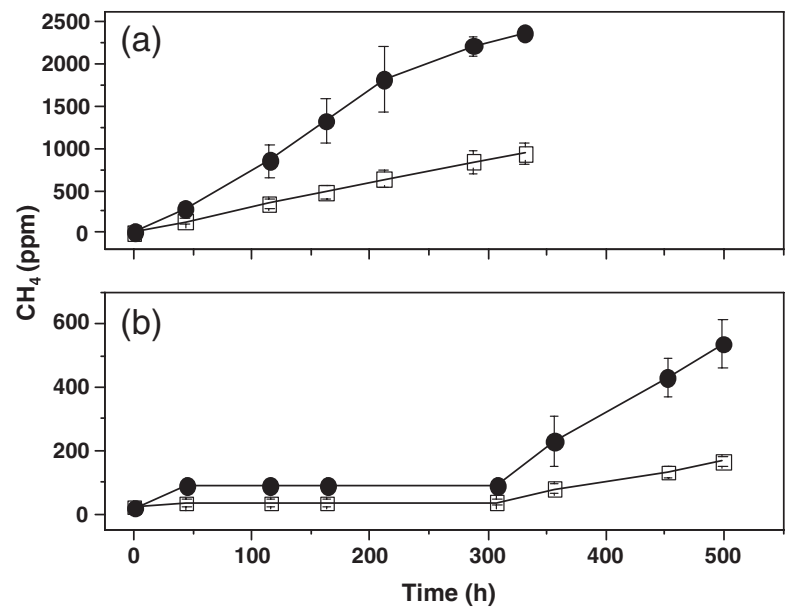

Fig. 3 Methanogenesis in permafrost soils at subzero temperatures. Soil samples were incubated at $-3^{\circ} \mathrm{C}$ (a) and $-6^{\circ} \mathrm{C}(\mathrm{b})$ with hydrogen (circles) or acetate (squares) as a substrate (means $\pm \mathrm{SE}, n=3$ ).

$\left(0.31 \pm 0.04\right.$ and $\left.0.04 \pm 0.01 \mathrm{nmol} \mathrm{CH}_{4} \mathrm{~h}^{-1} \mathrm{~g}^{-1}\right)$ at the corresponding temperatures.

\section{Microbial biomarkers}

Significant amounts of microbial biomarkers (bacterial and archaeal) were detected in sediment samples across all depth units (Fig. 4). Generally, microbial biomarkers were greatest in Unit I and lowest in Unit IV. Concen- trations of total biomarker (PLFA, UNSFA, UNOH and PLEL) varied between 3.9 and $66.2 \mathrm{nmol} \mathrm{g}^{-1}$. Biomarker concentrations of ester-linked PLFA (EL-PLFA) ranged between 0.7 and $43.5 \mathrm{nmolg}^{-1}$ and for archaeal PLEL, between 0.03 and $5.4 \mathrm{nmol} \mathrm{g}^{-1}$. Archaeal PLEL accounted for $4.1 \%$ of total biomarker in Unit I and for $0.7 \%$ in Unit IV.

\section{Compilation of relevant data sets}

The statistical analyses illustrate the relationships between organic matter quantity (TOC) and quality (HIX), methanogenic microorganisms (PLEL concentration) and activity, and the detected methane concentration in the permafrost sediments for the different core units (Fig. 5).

In Unit I five different PLEL-derived isoprenoids were detected. In contrast, all other units contained only one to three different PLEL side chains. These chains were much lower concentrated (Fig. 5a). Furthermore, in the same unit the PLEL side chain i20:1, characteristic for Methanosarcina spp. (Gattinger et al., 2002), accounted for $15.8 \%$ of total PLEL. In the other core units this compound was only detectable in trace amounts. Unit I also showed the highest activity of methanogenic archaea (Fig. 5b and c). A positive correlation was found between the organic carbon content (TOC) and methane production activity with acetate $(r=0.541, P=0.01)$ and with hydrogen $(r=0.532, P=0.01)$, and with methane content $(r=0.434, P=0.01)$ in the sediment. The correla- 
(a)

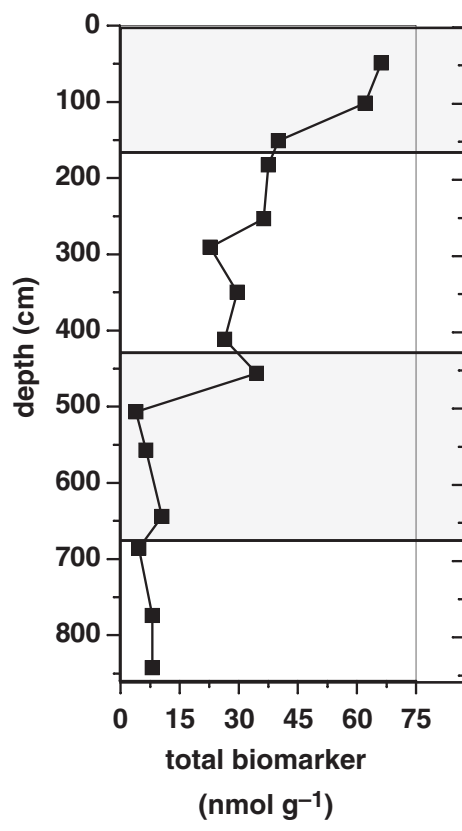

(b)

(c)

(d)

Fig. 4 Lipid biomarker profiles within the Holocene permafrost deposits of Samoylov Island, Lena Delta (Siberian Arctic). (a) Total biomarker, (b) ester-linked phospholipid fatty acids (EL-PLFA), (c) phospholipid ether lipids (PLEL) and (d) percentage of PLEL on total biomass. Units I-IV based on constrained incremental sum of squares (CONISS) analysis of the different grain size fractions.

tion between the amount of TOC and the HIX was negative $(r=-0.535, P=0.01)$.

\section{Discussion}

Our results show significant amounts of methane in the first $4 \mathrm{~m}$ of frozen sediments (Unit I and II, Late Holocene, 5000 BP until today) and only trace amounts of methane in the bottom section of the core (Unit III and IV; Middle Holocene, 9000-5000 BP; and Early Holocene, $11500-9000$ вр). Different amounts of methane in different aged permafrost deposits from north-eastern Eurasia were also reported by Rivkina \& Gilichinsky (1996). They detected methane in modern (Holocene) and old permafrost deposits (Middle and Early Pleistocene, 1.8-0.78 million year BP), but not in Late Pleistocene ice complexes (ice rich permafrost, 130000-11500years BP). They concluded from their findings that methane cannot diffuse through permafrost sections. If methane is unable to diffuse through permafrost from deeper deposits, it must be either be entrapped during the deposition of the sediments or originate from recent methanogenesis in the frozen ground.

The investigation of phospholipids shows a vertical profile with the same trend as the methane concentration. Specifically, significant amounts of phospholipids were determined in the upper Late Holocene deposits (Unit I, II), which correlates $(r=0.632, P=0.05)$ with the highest amount of methane in the permafrost section. In contrast, the biomarker concentrations in the Middle and Early Holocene permafrost sediments (Units III, IV) drastically decreased to values below $10 \mathrm{nmol} \mathrm{g}^{-1}$ sediment, which corresponds with the detected traces of methane.

PLFA are molecular biomarkers for the domains of Bacteria and Eukarya. PLEL are indicators for the domain Archaea. Phospholipids are compounds of the cell membranes that rapidly degraded after cell death (White et al., 1979; Harvey et al., 1986). They are regarded as appropriate biomarkers for viable microorganisms (e.g. Ringelberg et al., 1997; Zelles, 1999). The detection of biomarkers for viable microorganisms does not necessarily indicate their activity status. Enclosed in deep permafrost deposits, they can represent completely or partially inactive or dormant microorganisms (Colwell et al., 2005). A further possibility is that the detected PLFA and PLEL are well-preserved remains of ancient microbes. However, the positive correlation of methane concentration with viable bacteria and archaea gives us the first strong evidence of recent methanogenesis under in situ conditions in permafrost deposits.

The analyses of methane production revealed activity only in permafrost layers with significant concentrations of both methane and microbial (particularly archaeal) biomarkers. Although the activity in Unit I was higher compared with Unit II (both Late Holocene), 

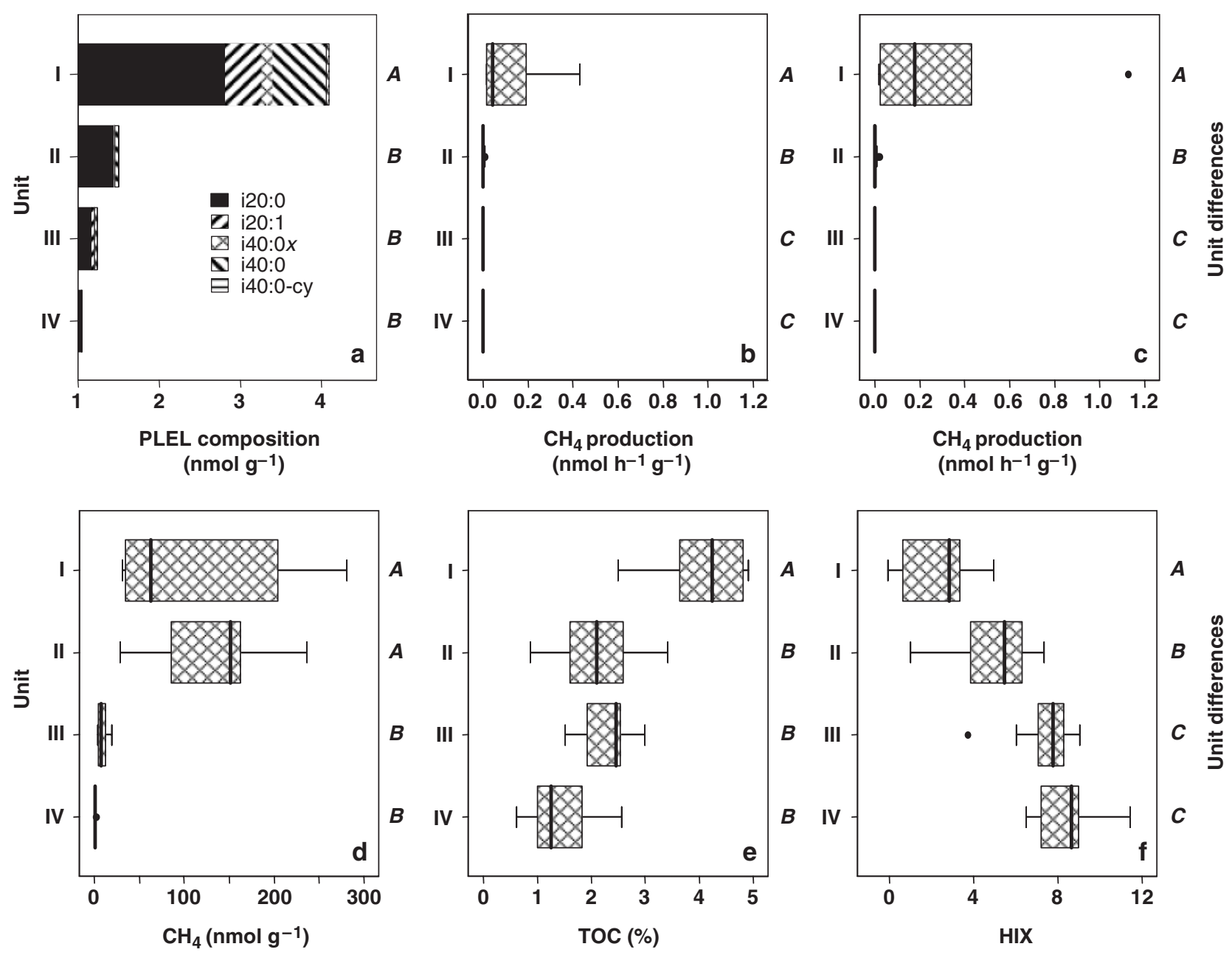

Fig. 5 Relationship between archaeal biomarkers (a), methane production activities with acetate (b) and hydrogen (c), methane concentration (d), organic matter quantity (TOC) and quality (HIX) for the different core units of the Holocene permafrost deposits. Different capitals indicate differences at the significance level of $P=0.05$.

which was also still characterized by high concentrations of methane, an important finding from the activity analyses is that no methane production was detectable in the bottom part of the permafrost section (Unit III, IV) characterized only by traces of methane. This was also the case after addition of acetate or $\mathrm{H}_{2} / \mathrm{CO}_{2}$ as energy and carbon source. This indicates the absence of methanogenesis does not depend on deficiency of methanogenic substrates in the Middle and Early Holocene deposits. Methane was only found in permafrost sediments with a considerable amount of viable microorganisms and verifiable methane production activity.

In Unit I (32-194 cm depth), archaeal biomass expressed as PLEL concentration, was highest and even exceeded values that were reported previously for the active layer at a related permafrost site (Wagner et al., 2005). In the present core, archaeal biomarkers accounted for $5.2 \%$ of total phospholipids in the upper section and for $2.3 \%$ of the entire profile. In addition, methanogenic PLEL chains (i20:1), indicative for Methanosarcina spp. (Gattinger et al., 2002), were detected in significant amounts only in Unit I. This finding was confirmed by isolates from the same study site identified as members of the genus Methanosarcina, which are characterized by extreme tolerance against various stress conditions (D. Morozova and D. Wagner, data under publication). This supports the hypothesis that Methanosarcina-like cells are better protected against damage caused by environmental stresses compared with other methanogens due to their typical formation of cell aggregates.

Although, only a few psychrophilic strains of methanogenic archaea have been isolated so far (Simankova et al., 2003; Cavicchioli, 2006), there are some indications of methanogenic activity in cold permafrost environments (Kotsyurbenko et al., 1993; Wagner et al., 2003a, b; 
Ganzert et al., 2007). However, this study actually revealed methane production under in situ permafrost temperature conditions of down to $-6^{\circ} \mathrm{C}$. The methane production rate with acetate or hydrogen at subzero temperatures was only 10 times lower compared with the activity in the active layer of a permafrost soil from the same study site (Wagner et al., 2005). This indicates a tolerance of permafrost methanogens to their cold environment. This assumption is also supported by the finding of Ganzert et al. (2007) who reported increasing methane production activity close to the permafrost table at low in situ temperature conditions. The zone of high methane concentrations in the permafrost deposits was characterized by in situ temperatures between approximately -2 and $-9{ }^{\circ} \mathrm{C}$. This is the same temperature range used in the incubation experiments.

One prerequisite for any metabolic activity in frozen permafrost sediments is the availability of unfrozen water. The Late Holocene permafrost deposits at the study site were characterized by a sediment texture of loamy sand with a relatively high content of silt and clay. In permafrost soils with a prominent part of finetextured material, liquid water has been observed at temperatures down to $-60^{\circ} \mathrm{C}$ (Ananyan, 1970). Biologically, the most important feature of unfrozen water in permafrost is the ability to transfer ions and nutrients (Ostroumov \& Siegert, 1996).

Additionally, the quality of organic carbon is a limiting factor in the microbial metabolism process. Our results reveal a high organic carbon content (on average 2.4\%) for the Holocene permafrost deposits. However, the quantity of organic matter in permafrost ecosystems provides no information on the quality, which determines the availability of organic compounds as energy and carbon sources for microorganisms (Hogg, 1993; Bergman et al., 2000). For this purpose, qualitative parameters like the HIX or the $\mathrm{C} / \mathrm{N}$ ratio can give suitable information with regard to microbial metabolism. Wagner et al. (2005) demonstrated that the availability of organic carbon in permafrost soils decreased with increasing HIX. This is in agreement with the present study. It was shown for the permafrost sequence the HIX increased continuously with depth. At the same time, the $\mathrm{C} / \mathrm{N}$ ratio and the organic carbon content decreased with permafrost depth. In both cases, this significantly correlates with the HIX. Consequently, at this point we can summarize that the zone with significant concentrations of methane and activity of methanogenic microorganisms is characterized by the highest concentration of high-quality organic carbon.

In contrast to the results of the soil-ecological variables (methane production activity, PLEL biomarker concentration, TOC, HIX), we do not achieve any ideas for a possible entrapment process of methane during sedimentation from data of paleoclimate research (Andreev et al., 2004; Andreev \& Klimanov, 2005).

In the Early Holocene to approximately 8800 BP, the environmental conditions were relatively stable in comparison to the Late Holocene (5000 BP until today). This was shown by climate reconstruction based on pollen and chironomid records from the Lena Delta (Andreev et al., 2004). They determined the Holocene climate optimum between 10300 and 9200 BP, which was characterized by warmer (up to $3{ }^{\circ} \mathrm{C}$ ) and wetter conditions than the present day. Between 9200 and 6000 BP, the climate was still relatively warm but more unstable concerning the temperature. From the climate reconstruction, it can be concluded that the environmental conditions during the Early Holocene until 8800 BP were favourable for methanogenic archaea and methanogenesis. The absence of methane in the permafrost sediments from this period indicates that the likely produced methane was emitted to the atmosphere before it could be entrapped by freezing of the sediments. It can be expected that under more unstable conditions methane production is low or no methanogenesis occurred. However, the highest methane concentrations were detected in sediments $(<8800$ вр until present) deposited under such conditions, indicating an accumulation of the methane over longer periods by in situ activity. This gives us evidence for the prediction that the methane concentration profile rather depends on in situ activity of methanogenic archaea than on the inclusion of methane during sedimentation processes.

More than 20\% of the terrestrial Arctic is characterized by ice rich permafrost (Zhang et al., 1999). Large areas, mainly dominated by continuous permafrost, exist in Siberia with thicknesses up to $900 \mathrm{~m}$ (Yershov, 1998). The present study revealed considerable parts of these cold habitats as recent sites of methane production, probably catalysed by specific cold-adapted methanogenic archaea. This increasing reservoir of climate relevant trace gases becomes of major importance against the background of global warming which could result from a thawing of permafrost area up to 25\% until 2100 (Anisimov et al., 1999) and subsequent disposal of the methane reservoirs into the atmosphere. Today, more than $75 \times 10^{6} \mathrm{t}$ permafrost sediments $\mathrm{a}^{-1}$ are eroded at the Laptev Sea coast (Rachold et al., 2000), from which a theoretical methane release of about $100 \mathrm{tCH}_{4} \mathrm{a}^{-1}$ can be calculated. These quantities are not considered in regional and global greenhouse gas balances and modelling. This is of particular importance as our results reveal a substantial increase of the microbial methane production in the frozen ground, if the permafrost temperature arises from -6 to $-3^{\circ} \mathrm{C}$. 


\section{Conclusions}

This work shows for the first time that microorganisms, particularly methanogenic archaea, do not only survive in permafrost habitats but also can be metabolic active under in situ conditions. Owing to the subzero experiments and the in situ temperatures of permafrost sediments, we can conclude that the methanogenic community is dominated by psychrotolerant or even psychrophilic microorganisms. Despite this adaptation to cold environments, we show that a slight increase of the temperature can lead to a substantial increase of methanogenic activity. In case of permafrost degradation, this would lead to an extensive expansion of the methane deposits with their subsequent impacts on total methane emission. A future in-depth characterization of the metabolism of these cold-adapted methanogens will reveal biotic and abiotic factors, which influence the methanogenic activity of these organisms.

The results further show that methane in permafrost, which originates from modern methanogenesis, represents contribution thus so far not considered to the global methane budget. The methane is released to the atmosphere by permafrost degradation in form of thermokarst or coastal erosion processes, which is an ongoing process in Arctic regions. Although the change of permafrost by global warming is examined in the framework of different international projects (e.g. ACD, Arctic Coastal Dynamics, CALM, Circumpolar Active Layer Monitoring), these investigations should be linked more strongly with microbiological process studies and biodiversity research. Thus, a contribution could be made to understand the role of permafrost in the global system and possible feedbacks by material fluxes and greenhouse gas emissions.

\section{Acknowledgements}

The authors wish to thank the Russian-German field parties during the LENA 2001 expedition, especially Christian Wille and Günter 'Molo' Stoof (Alfred Wegener Institute for Polar and Marine Research) for their assistance with the drilling device. Furthermore, we want to thank Dimitri V. Melnitschenko (Hydro Base Tiksi) and Waldemar Schneider (Alfred Wegener Institute for Polar and Marine Research) for logistic support during the expedition. Finally, we thank Ulrike Herzschuh for helpful discussion with regard to the grain size interpretation and William R. Bolton for critical reading of the manuscript (both Alfred Wegener Institute for Polar and Marine Research). The study is part of the German-Russian project The Laptev Sea System (03G0534G), which was funded by the German Ministry of Education and Research (BMBF) and the Russian Ministry of Research and Technology.

\section{References}

Ananyan AA (1970) Unfrozen water content in frozen clay at a temperature from $-0.6{ }^{\circ} \mathrm{C}$ to $-40{ }^{\circ} \mathrm{C}--60^{\circ} \mathrm{C}$. Merzlotnye Issledovaniya, 10, 267-270 (in Russian).
Andreev A, Klimanov A (2005) Late-Glacial and Holocene in Chapter 5 East Siberia (based on data obtained mainly in Central Yakutia). Geological Society of America Bulletin, 382, 98-102.

Andreev A, Tarasov P, Schwamborn G et al. (2004) Holocene paleoenvironmental records from Nikolay Lake, Lena River Delta, Arctic Russia. Palaeogeography, Palaeoclimatology, Palaeoecology, 209, 197-217.

Anisimov OA, Nelson FE, Pavlov AV (1999) Predictive scenarios of permafrost development under conditions of global climate change in the XXI century. Earth Cryology, 3, 15-25.

Bartlett KB, Harriss RC (1993) Review and assessment of methane emissions from wetlands. Chemosphere, 26, 261-320.

Bergman I, Klarqvist M, Nilsson M (2000) Seasonal variation in rates of methane production from peat of various botanical origins: effects of temperature and substrate quality. FEMS Microbiology Ecology, 33, 181-189.

Cao M, Gregson K, Marshall S (1998) Global methane emission from wetlands and its sensivity to climate change. Atmospheric Environment, 32, 3293-3299.

Cavicchioli R (2006) Cold-adapted archaea. Nature Review Microbiology, 4, 331-343.

Colwell FS, Nunoura T, Delwiche ME et al. (2005) Evidence of minimal methanogenic numbers and activity in sediments collected from the JAPEX/JNOC/GSC et al. Mallik 5L-38 Gas Hydrate Production Research Well. In: Scientific Results from Mallik 2002 Gas Hydrate Production Research Well Program, Mackenzie Delta, Northwest Territories, Canada. Bulletin 585 (eds Dallimore SR, Collett TS), pp. 1-11. Geological Survey of Canada, Microbiology section.

French HM (1996) The Periglacial Environment. Longman, Westminster.

Ganzert L, Jurgens G, Münster U, Wagner D (2007) Methanogenic communities in permafrost-affected soils of the Lepter Sea coast, Siberian Arctic, characterized by $16 \mathrm{~S}$ rRNA gene fingerprints. FEMS Microbiology Ecology, 59, 476-488.

Gattinger A, Günthner A, Schloter M, Munch JC (2003) Characterisation of archaea in soil ecosystems by polar lipid analysis. Acta Biotechnology, 23, 21-28.

Gattinger A, Schloter M, Munch JC (2002) Phospholipid etherlipid and phospholipid fatty acid fingerprints in selected euryarchaeotal monocultures for taxonomic profiling. FEMS Microbiology Letters, 213, 133-139.

Gounot AM (1999) Microbial life in permanently cold soils. In: Cold-adapted Organisms (eds Margesin R, Schinner F), pp. 3-16. Springer, Berlin.

Harvey HR, Fallon RD, Patton JS (1986) The effect of organic matter and oxygen on the degradation of bacterial membrane lipids in marine sediments. Geochimica et Cosmochimica Acta, 50, 795-804.

Hogg EH (1993) Decay potential of hummock and hollow Sphagnum peats at different depths in a Swedish raised bog. Oikos, 66, 269-278.

Hubberten H-W, Wagner D, Pfeiffer E-M, Boike J, Gukov AY (2006) The Russian-German research station Samoylov, Lena Delta - a key site for polar research in the Siberian arctic. Polarforschung, 73, 111-116.

IPCC (2001) Climate change 2001: the scientific basis. In: Contribution of the Working Group I to the Third Assessment Report of 
the Intergovernmental Panel on Climate Change (eds Houghton JT, Ding Y, Griggs DJ, Nogner M, van der Linden PJ, Dai X, Maskell K, Johnson CA), Cambridge University Press, Cambridge, New York, 0-881.

Kobabe S, Wagner D, Pfeiffer E-M (2004) Characterization of microbial community composition of a Siberian tundra soil by fluorescence in situ hybridization. FEMS Microbiology Ecolol$o g y$, 50, 13-23.

Kotsyurbenko OR, Nozhevnikova AN, Zavarzin GA (1993) Methanogenic degradation of organic matter by anaerobic bacteria at low temperature. Chemosphere, 27, 1745-1761.

Liebner S, Wagner D (2007) Abundance, distribution and potential activity of methane oxidizing bacteria in permafrost soils from the Lena Delta, Siberia. Environmental Microbiology, 9, 107-117.

Lipski A, Altendorf K (1997) Identification of heterotrophic bacteria isolated from ammonia-supplied experimental biofilters. System Applied Microbiology, 20, 448-457.

Mangelsdorf K, Haberer RM, Zink KG et al. (2005) Molecular indicators for the occurrence of deep microbial communities at the JAPEX/JNOC/GSC et al. Mallik 5L-38 Gas Hydrate Production Research Well. In: Scientific Results from Mallik 2002 Gas Hydrate Production Research Well Program, Mackenzie Delta, Northwest Territories, Canada. Bulletin 585 (eds Dallimore SR, Collett TS), pp. 18-29. Geological Survey of Canada, Microbiology section.

Nadeau MJ, Grootes PM, Schleicher M, Hasselberg P, Rieck A, Bitterling M (1998) Sample throughput and data quality at the Leibniz-Labor AMS facility. Radiocarbon, 40, 239-245.

Nadeau MJ, Schleicher M, Grootes PM, Erlenkeuser H, Gottdang A, Mous DJW, Sarnthein JM, Willkomm H (1997) The LeibnizLabor facility at the Christian Albrecht University, Kiel, Germany. Nuclear Instruments and Methods in Physics Research, 123, 22-30.

Nichols PD, Guckert JB, White DC (1986) Determination of monounsaturated fatty acid double-bond position and geometry for microbial monocultures and complex consortia by capillary GC-MS of their dimethyl disulphide adducts. Journal of Microbiological Methods, 5, 49-55.

Oechel WC, Callaghan T, Gilmanov Tet al. (1997) Global Change and Arctic Terrestrial Ecosystems. Ecological Studies, Vol. 124. Springer, Berlin.

Ostroumov V, Siegert C (1996) Exobiological aspects of mass transfer in microzones of permafrost deposits. Advances in Space Research, 18, 79-86.

Rachold V, Grigoriev MN, Are FE, Solomon S, Reimnitz E, Kassens H, Antonow M (2000) Coastal erosion vs riverine sediment discharge in the Arctic Shelf seas. International Journal of Earth Sciences, 89, 450-460.

Richter-Menge J, Overland J, Proshutinsky A et al. (2006) State of the Arctic Report. NOAA OAR Special Report, NOAA/OAR/ PMEL, Seattle, WA, 36 pp.

Ringelberg DB, Sutton S, White DC (1997) Biomass, bioactivity and biodiversity: microbial ecology of the deep subsurface: analysis of ester-linked phospholipid fatty acids. FEMS Microbiology Reviews, 20, 371-377.
Rivkina EM, Friedmann EI, McKay CP, Gilichinsky DA (2000) Metabolic activity of permafrost bacteria below the freezing point. Applied Environmental Microbiolology, 66, 3230-3233.

Rivkina EM, Gilichinsky DA (1996) Methane as a paleoindicator of the dynamics of permafrost deposits. Limnology and Mineral Resources, 31, 396-399.

Rivkina EM, Gilichinsky D, Wagener S et al. (1998) Biochemical activity of anaerobic microorganisms from buried permafrost sediments. Geomicrobiology, 15, 187-193.

Russel NJ, Hamamoto T (1998) Psychrophiles. In: Extremophiles: Microbial Life in Extreme Environments (eds Horikoshi K, Grant WD), pp. 25-45. John Wiley, New York.

Senesi N, Miano TM, Provenzano MR, Brunetti G (1989) Spectroscopic and compositional comparative characterization of I.H.S.S reference and standard fulvic and humic acids of various origin. Science of the Total Environment, 81, 143-156.

Shi T, Reevers R, Gilichinsky D, Friedmann EI (1997) Characterization of viable bacteria from Siberian permafrost by $16 \mathrm{~S}$ rDNA sequencing. Microbial Ecology, 33, 167-179.

Simankova MV, Kotsyurbenko OR, Lueders T, Nozhevnikova AN, Wagner B, Conrad R, Friedrich MW (2003) Isolation and characterization of new strains of methanogens from cold terrestrial habitats. Systematic and Applied Microbiology, 26, 312-318.

Stuiver M, Reimer PJ, Braziunas TF (1998) High-precision radiocarbon age calibration for terrestrial and marine samples. Radiocarbon, 40, 1127-1151.

Wagner D, Kobabe S, Pfeiffer E-M, Hubberten H-W (2003a) Microbial controls on methane fluxes from a polygonal tundra of the Lena Delta, Siberia. Permafrost Periglac Process, 14, 173-185.

Wagner D, Lipski A, Embacher A, Gattinger A (2005) Methane fluxes in permafrost habitats of the Lena Delta: effects of microbial community structure and organic matter quality. Environmental Microbiology, 7, 1582-1592.

Wagner D, Wille C, Kobabe S, Pfeiffer E-M (2003b) Simulation of freezing-thawing cycles in a permafrost microcosm for assessing microbial methane production under extreme conditions. Permafrost and Periglacial Processes, 14, 367-374.

White DC, Davis WM, Nickels JS, King JD, Bobbie RJ (1979) Determination of the sedimentary microbial biomass by extractible lipid phosphate. Oecologia, 40, 51-62.

Yershov ED (1998) General Geochryology. Cambridge University Press, Cambridge.

Zelles L (1999) Fatty acid patterns of phospholipids and lipopolysaccharides in the characterisation of microbial communities in soil: a review. Biology and Fertility of Soils, 29, 111-129.

Zelles L, Bai QY (1993) Fractionation of fatty acids derived from soil lipids by solid phase extraction and their quantitative analysis by GC-MS. Soil Biology and Biochemistry, 25, 495-507.

Zhang T, Barry RG, Knowles K, Heginbottom JA, Brown J (1999) Statistics and characteristics of permafrost and ground-ice distribution in the Northern Hemisphere. Polar Geography, 2, 132-154.

Zsolnay A (2003) Dissolved organic matter: artefacts, definitions, and functions. Geoderma, 113, 187-209.

Zsolnay A, Baigar E, Jiminez M, Steinweg B, Saccomandi F (1999) Differentiation with flourescence spectroscopy the sources of dissolved organic carbon. Chemosphere, 38, 45-50. 